\title{
Reproductive cycle of the swimming crab Portunus spinimanus Latreille (Crustacea, Decapoda, Brachyura) from Ubatuba, São Paulo, Brazil
}

\author{
Sandro Santos 1,3 \\ Maria Lucia Negreiros-Fransozo ${ }^{2,3}$
}

\begin{abstract}
This study analyses some reproductive aspects of Portunus spinimanus Latreille, 1819 , a crab usually commercialized in Ubatuba region. Monthly otter-trawl collections were taken for two years along the northern coast of São Paulo State, Brazil. The reproductive period was studied based on the frequency of ovigerous females in the population along the year; the frequency of physiologically mature swimming crabs and the type of spawn. The condition of development of ovigerous females ovary was associated with the stage of eggs development. This species presents continuous reproduction in Ubatuba region and total spawn, but with successive broods, which suggests a multiple spawn during the reproduction period.

KEY WORDS. Portunus spinimanus, reproduction, spawn, Brazilian coast
\end{abstract}

Among crustaceans there is a great variation of reproduction patterns, mainly when habitat is considered. According to SASTRY (1983) specific procreation variations may be explained as a genotypical response to environment, to obtain reproduction success under favorable conditions. A population may show continuous reproduction, if it lays eggs with approximately the same intensity all through the year, or discontinuous, if the spawn is more intense during a certain time of the year (SASTRY 1983)

Some crabs from the southwest of India reproduce for a long period of time, or for the whole year, such as Portunus sanguinolentus (Herbst), Charybdis cruciata (Herbst), while $P$. pelagicus (Linnaeus, 1758) during nine months, from August to April, with the peak between December and January (PILLAY \& NAIR 1971). On the east coast of India, P. pelagicus breeds continuously, according to RYAN (1967).

The spawning, therefore, takes place in different months in different areas when the population has a wide distribution. The temperate zone crab, Cancer irroratus (Say, 1817) procreates from October to August, with the peak between February and May in Maine (USA), while another population further down south, in Chesapeake Bay, reproduces from September to June, with the peak between March and April (HAEFNER 1976).

1) Departamento de Biologia, Centro de Ciências Naturais e Exatas, Universidade Federal de Santa Maria. 97105-900 Santa Maria, Rio Grande do Sul, Brasil.

2) Departamento de Zoologia, Instituto de Biociências, Centro de Aqüicultura, Universidade Estadual Paulista. 18618-000 Botucatu, São Paulo, Brasil.

3) NEBECC, Group of Studies on Crustacean Biology, Ecology and Culture. 
Therefore, besides temperature which, as has already been mentioned, can affect the reproductive period of a species, the pattern of reproduction may be synchronized with other factors, such as duration of daytime, abundance of food for larvae, moon and tide rhythm or still, according to BATOY et al. (1987), changes in salinity, or even a combination of all these factors. Synchronism is more evident in species which dwell in areas where seasonal variations are more pronounced.

During the spawn females may lay eggs only once when all ovocytes which are present in the ovary mature and are expelled together, characterizing a total spawn. There are also parcel egg batches when the eggs mature in lots are expelled at regular intervals. In crabs it is possible to capture ovigerous females with fully grown gonads, indicating more than one spawn per interchanging period (SUMPTON 1990).

This paper describe the reproductive period and the type of spawn of $P$. spinimanus Latreille, 1819 , a swimming crab usually commercialized in the Ubatuba region, São Paulo, Brazil.

\section{MATERIAL AND METHODS}

The presence of $P$. spinimanus is associated with gravel and very coarse sand (SANTOS et al. 1994). In this study, monthly collections were taken for two years (May/91 to April/93) in Ubatuba, on the northern coast of the state of São Paulo, Brazil. The sites were occupied mainly by animals with size similar or greater than the size of first maturity (SANTOS et al. 1995). An otter-trawl with $15 \mathrm{~mm}$ side mesh and $10 \mathrm{~mm}$ cod end mesh was used to collect sample by approximately one hour in each month.

In the laboratory, the number of animals sampled in each month and their sex were recorded. After dissection of each individual, the gonadal stages of development were characterized as the description presented in table I (original description by autors).

The reproductive period of the species was determined based on the frequency of ovigerous females in the population through the year, by the frequency of physiologically mature individuals, i.e., with developed or developing gonads which allow them to copulate successfully. Among females, those with ovaries at an "advanced", "intermediary" or "developing" stage of development were considered to be mature. Among males, those with "developing" or "developed" gonads were considered to be mature.

The type of spawn was determined by the association between the condition of ovigerous females ovary with the stage of development of the eggs as follows: initial stage, egg mass orange coloring due to the large amount of vitellus; intermediary stage, mass light brown to gray and the larval eyes can already be observed; final stage, egg mass dark brown to black and the larvae are completely formed within the membrane which covers the egg.

The presence of ovigerous females in the population and the stages of gonad development for both sexes were correlated with the average surface temperature of the water in each month of collection. The average temperature for surface and bottom are similar at the sites studied according to NEGREIROS-FRANSOZO et al. (1991). 
Table I. Characterization of stages of gonad development in males and females of the species P. spinimanus.

\begin{tabular}{|c|c|c|}
\hline \multirow{2}{*}{ Stage } & \multicolumn{2}{|c|}{ Characteristics } \\
\hline & Males & Females \\
\hline Immature (IM) & $\begin{array}{l}\text { No differentiated gonads. Impossible to recognize } \\
\text { gonad and vas deferent. }\end{array}$ & $\begin{array}{l}\text { No differentiated gonads. Stage of gonad } \\
\text { development coincides with stage of } \\
\text { morphological maturation (SANTOS et al. 1995). }\end{array}$ \\
\hline Rudimentary (RU) & $\begin{array}{l}\text { Gonads are recognized only by magnifying. Vas } \\
\text { deferent can be observed behind the stomach. } \\
\text { Gonad looks filamentous and coloring is pale- } \\
\text { yellow. }\end{array}$ & $\begin{array}{l}\text { Undeveloped gonads look filamentous, thin and } \\
\text { with pale yellow color. }\end{array}$ \\
\hline Developing (DG) & $\begin{array}{l}\text { Gonads are visible in the anterolateral region of the } \\
\text { abdominal cavity. Vas deferent can be divided in } \\
\text { two different regions, the front one being thinner. } \\
\text { Gonad/hepatopancreas ratio is } 1 / 4 \\
\text { approximately. }\end{array}$ & $\begin{array}{l}\text { Beginning of ovary maturation. Gonad/ } \\
\text { hepatopancreas ratio is } 1 / 8 \text { approximately. } \\
\text { Yellow color. Connection between right and left } \\
\text { trumpet are clear. }\end{array}$ \\
\hline Developed (DD) & $\begin{array}{l}\text { Gonad reaches its highest development. Vas } \\
\text { deferent can be clearly divided in front, median } \\
\text { and back. Vessels look entwined. Gonad/ } \\
\text { hepatopancreas ratio is } 1 / 2 \text { approximately. }\end{array}$ & - \\
\hline Intermediary (INT) & - & $\begin{array}{l}\text { Ovary bright orange. Gonad/hepatopancreas ratio } \\
\text { is } 1 / 2 \text { approximately. Ovary looks lobated. }\end{array}$ \\
\hline Advanced (AD) & - & $\begin{array}{l}\text { Ovary fills almost the whole toraxic cavity. Bright } \\
\text { orange color. Lobated look is more evident than } \\
\text { in previous stage. }\end{array}$ \\
\hline Redevelopment (RE) & - & $\begin{array}{l}\text { Stage attributed to ovigerous females. It can be } \\
\text { subdivided in to RE/RU, RE/DG, RE/INT and } \\
\text { RE/AD }\end{array}$ \\
\hline
\end{tabular}

The study of the reproductive period, based on the comparison of the degrees of interest was analyzed using the test of GoODMAN $(1964,1965)$ for contrasts between and within multinomial populations (in this case, binomial). The results were discussed considering the significance level of $5 \%$.

The differences in temperature between the months of collection during the two years of the study were determined by means of a variance test for totally casualized experiments, complemented with the multiple comparison test of Tuckey (COCHRAN \& COX 1978).

The association between the reproductive period and the average temperature in each month of collection was analyzed through the adjustment of linear functions or functions likely to be made linear, according to DRAPER \& SMITH (1966).

\section{RESULTS}

A total of 1733 crabs were analized, 578 males (496 adults and 82 juveniles) and 1155 females (67 juveniles, 566 ovigerous and 522 non-ovigerous adults) (Tab. II).

Frequency of ovigerous females in population: Ovigerous females were collected in all sampling months. The percentage of ovigerous females, in relation to the total amount of adult females collected every month, during the first and second year of study is shown in figure 1 . 


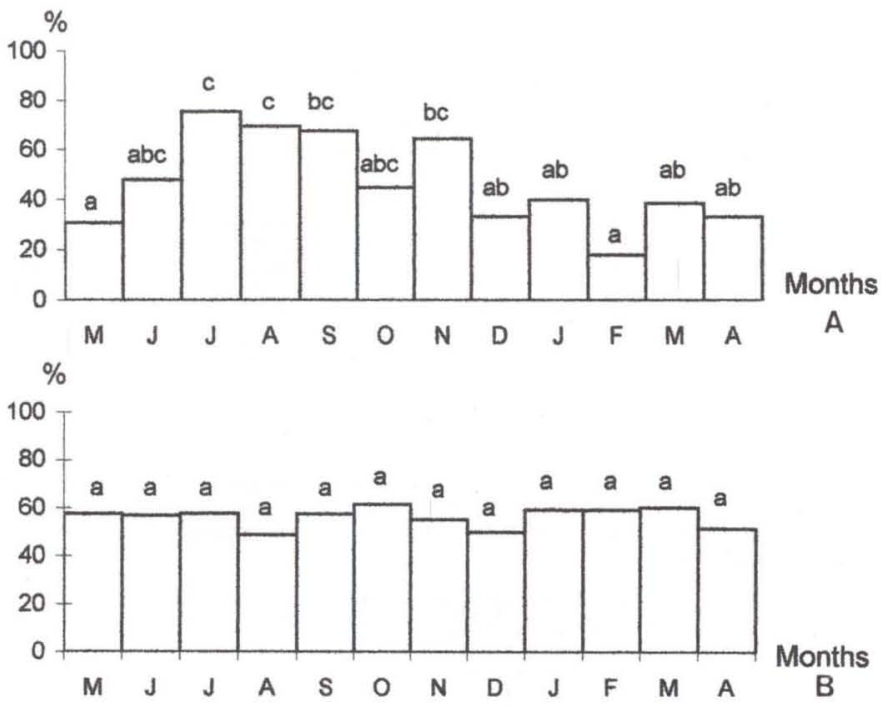

Fig. 1. Percentage of ovigerous females in relation to the total number of captured adult females, in each month of collection, in the first $(A)$ and second $(B)$ years. Months with similar letters do not differ.

Table II. Number of animals sampled in each months: males (juveniles and adults) and females (mature, ovigerous and juveniles).

\begin{tabular}{|c|c|c|c|c|c|c|}
\hline \multirow[t]{2}{*}{ Months } & \multirow[t]{2}{*}{$\mathrm{N}$} & \multicolumn{2}{|c|}{ Males } & \multicolumn{3}{|c|}{ Females } \\
\hline & & Adults & Juveniles & Adults & Ovigerous & Juveniles \\
\hline \multicolumn{7}{|l|}{ First year } \\
\hline May & 86 & 21 & 0 & 65 & 20 & 0 \\
\hline June & 40 & 13 & 0 & 27 & 13 & 0 \\
\hline July & 61 & 20 & 0 & 41 & 31 & 0 \\
\hline August & 55 & 7 & 1 & 46 & 32 & 1 \\
\hline September & 56 & 17 & 1 & 34 & 23 & 4 \\
\hline October & 57 & 14 & 2 & 40 & 18 & 1 \\
\hline November & 57 & 11 & 0 & 45 & 29 & 1 \\
\hline December & 54 & 15 & 12 & 18 & 6 & 9 \\
\hline January & 92 & 12 & 10 & 50 & 20 & 20 \\
\hline February & 143 & 57 & 26 & 44 & 8 & 16 \\
\hline March & 97 & 32 & 12 & 44 & 17 & 9 \\
\hline April & 66 & 18 & 9 & 36 & 12 & 3 \\
\hline \multicolumn{7}{|l|}{ Second year } \\
\hline May & 95 & 38 & 3 & 54 & 31 & 0 \\
\hline June & 67 & 23 & 0 & 44 & 25 & 0 \\
\hline July & 60 & 21 & 1 & 38 & 22 & 0 \\
\hline August & 59 & 16 & 0 & 43 & 21 & 0 \\
\hline September & 84 & 23 & 0 & 61 & 35 & 0 \\
\hline October & 85 & 19 & 1 & 65 & 40 & 0 \\
\hline November & 115 & 29 & 1 & 85 & 47 & 0 \\
\hline December & 63 & 28 & 2 & 32 & 16 & 1 \\
\hline January & 49 & 16 & 0 & 32 & 19 & 1 \\
\hline February & 35 & 8 & 0 & 27 & 16 & 0 \\
\hline March & 77 & 24 & 0 & 53 & 32 & 0 \\
\hline April & 80 & 14 & 1 & 64 & 33 & 1 \\
\hline Total & 1733 & 496 & 82 & 1088 & 566 & 67 \\
\hline
\end{tabular}


In the first year, significant differences were registered between the months of May and February, which showed lower rates of incidence, in relation to the months of July and August, September and November, with higher incidence. In the second year of sampling no significant differences were registered in the number of ovigerous females between months (Fig. 1).

The number of ovigerous females in the first year of sampling was lower than the number of non-ovigerous females, 229 and 261 animals, respectively. In the second year, this relation was inverted, 337 ovigerous and 261 non-ovigerous. When the two years are compared, the second year showed a higher number of ovigerous females than the first year.

Frequency of females with mature gonads in population: Comparing the percentages of mature females in each month of first year of this study the frequences of mature females was more than $70 \%$, from May until November and in April, while in February were registered only $34.6 \%$. During the course of the second year of study no significant differences were registered between months, i.e., the frequency of mature females remained constant (Fig. 2).

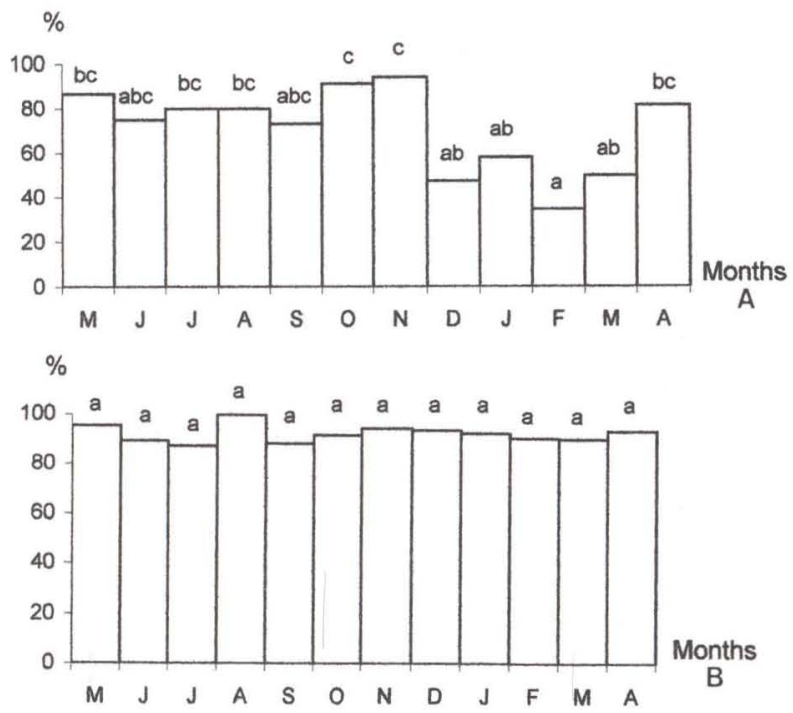

Fig. 2. Percentage of females with mature gonads in each month of collection, in the first (A) and second $(B)$ years. Months with similar letters do not differ.

In the first and second year of sampling, the number of females with mature gonads was higher than the number of females with immature gonads. The second year showed a higher number of mature females, when compared to the first year (above $90 \%$, approximately).

Frequency of males with mature gonads in population: In the first year of the work, significant differences were registered between males with mature gonads only in the months of July (high rate) and February (low rate). In the remaining 
months the frequency remained constant (Fig. 3), whilst in the second year no differences were registered in the incidence of males with mature gonads between months.
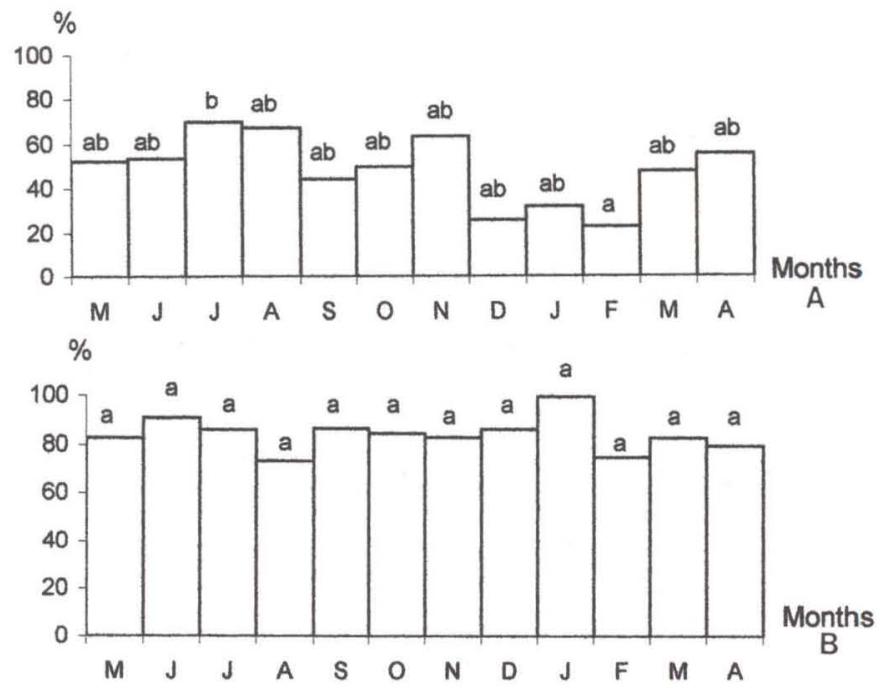

Fig. 3. Percentage of males with mature gonads in each month of collection, in the first $(A)$ and second $(B)$ years. Months with similar letters do not differ.

Comparing the two years of sampling, in the first the number of immature individuals (stages immature and rudimentary) was higher than the number of mature individuals, in opposition to the second year, when the number of mature individuals was higher.

Type of spawn: two hundred and fifty seven out of 594 analyzed ovigerous females (566 of regular samples and 28 extra) carried eggs at the initial stage, 222 carried eggs at the intermediary stage and 115 at the final stage of development. The majority of the captured ovigerous females carried eggs at the initial stage of development and $70 \%$ of these showed gonads at the beginning of re-development, stage RE/DG, whilst among the females that were captured with eggs at the final stage of development, the majority, also $70 \%$, showed gonads at the stage RE/AD (Fig. 4). After ovulation the number of oocytes in the ovaries must be practically nil and thus, in $P$. spinimanus, the egg batch is complete.

In the course of both years of study, significant temperature variations were obtained between months (Tab. III).

In the first year there was an inverse relation between the reproductive period and temperature. After the month of May, when temperature started to drop, the frequency of ovigerous females raised. In September, when temperature started to rise, the frequency of ovigerous females fell. In the second year, the frequency of ovigerous females in the population is not associated to temperature, as showed by the statistical analysis (Tab. IV). 


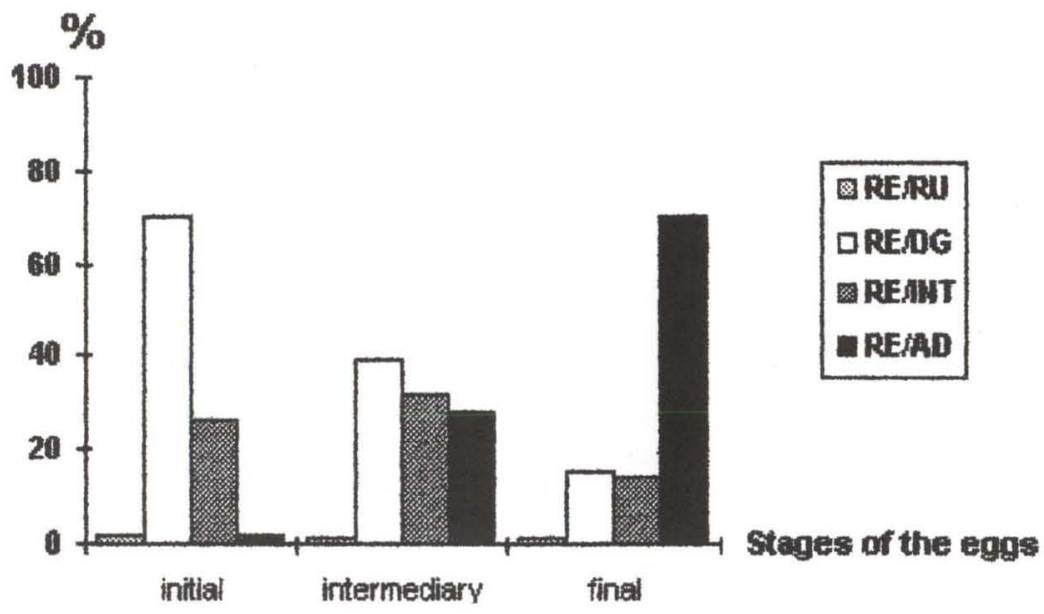

Fig. 4. Percentage of ovigerous females with gonads at stages RE/RU, RE/DG, RE/INT and $\mathrm{RE} / \mathrm{AD}$, associated with the stages of development of the eggs (Initial, Intermediary and Final Stages).

Table III. Variation analysis of the average surface temperatures $\left({ }^{\circ} \mathrm{C}\right)$ registered each month of sampling during the first and second years of study and the result of the Tuckey test referring to comparisons.

\begin{tabular}{lll}
\hline \multirow{2}{*}{ Months } & \multicolumn{2}{c}{ Average temperratures } \\
\cline { 2 - 3 } & First year & Second year \\
\cline { 2 - 3 } May & $24.6 \mathrm{~d}$ & $24.4 \mathrm{~d}$ \\
June & $23.6 \mathrm{~d}$ & $23.7 \mathrm{~cd}$ \\
July & $22.1 \mathrm{~b}$ & $22.1 \mathrm{~b}$ \\
August & $21.6 \mathrm{~b}$ & $20.8 \mathrm{a}$ \\
September & $20.2 \mathrm{a}$ & $21.3 \mathrm{ab}$ \\
October & $22.0 \mathrm{~b}$ & $23.4 \mathrm{c}$ \\
November & $24.0 \mathrm{~cd}$ & $25.0 \mathrm{de}$ \\
December & $27.0 \mathrm{fg}$ & $25.4 \mathrm{e}$ \\
January & $27.5 \mathrm{~g}$ & $28.0 \mathrm{fg}$ \\
February & $26.1 \mathrm{ef}$ & $28.7 \mathrm{gh}$ \\
March & $25.6 \mathrm{e}$ & $28.9 \mathrm{~h}$ \\
April & $25.9 \mathrm{e}$ & $27.5 \mathrm{f}$ \\
\hline
\end{tabular}

$\left({ }^{*}\right)$ Months with similar letters do not differ.

During the two years, gonad activity, for males as well as females, showed associations that were similar to the frequency of ovigerous females in relation to temperature, i.e., an inverse relation in the first year and absence in the second year (Tab. IV).

Table IV. Pearson linear correlation ratio between temperature and frequency of ovigerous females, frequency of females with mature gonads and frequency of males with mature gonads.

\begin{tabular}{lcc}
\hline \multicolumn{1}{c}{ Desired association } & First year & Second year \\
\hline$T\left({ }^{\circ} \mathrm{C}\right) \times$ Ovigerous females & $-0.77(p<0.01)$ & $0.26(p>0.05)$ \\
$T\left({ }^{\circ} \mathrm{C}\right) \times$ Females with mature gonads & $-0.62(p<0,05)$ & $0.31(p>0.05)$ \\
$T\left({ }^{\circ} \mathrm{C}\right) \times$ Males with mature gonads & $-0.60(p<0.05)$ & $0.06(p>0,05)$ \\
\hline
\end{tabular}




\section{DISCUSSION}

The species $P$. spinimanus, in the region of Ubatuba, SP, reproduces throughout the year, as evidenced through the ways used herewith. Differences in the reproductive activity between months were detected only in the first year.

In Florida, ovigerous females of this species were captured only in five months of the year, according to CAMP et al. (1977). DUDLEY \& JUDY (1971) mention the presence of ovigerous females of $P$. spinimanus from May to October in North Carolina and OLSEN et al. (1978), from February to March in Virgin Island. As may be verified, the reproductive period of this species varies from place to place. These variations may be explained by environmental differences or even by sampling problems. Environmental differences are observed mainly in species which are spread over very different latitudes. As a response to environment changes, the species' metabolism may behave in a different way and therefore affect upgrowth, behavior and the animals' reproductive success (SASTRY 1983).

When stating that environment can influence the reproduction of a population, one must take into consideration the physical, chemical and biotic factors, and the interactions, such as competition, predation and social structures.

The most usual way to establish the reproductive period in crabs is the frequency of ovigerous females. In this study, the peak of procreation was between July and November in the first year. As for gonad development in females, the period is similar (May to November). Amongst males, the peak occurred in June.

Comparing the way that use gonad development and the frequency of ovigerous females, an increase of gonad activity may occur shortly before the beginning of the rise in the number of ovigerous females of the population. This is noticed, mainly, when the second year of study is analyzed. This is to be expected, as the gonad development precedes egg extrusion.

As there are temperature variations between the months of collection, it would be normal to expect that this factor should influence the reproductive cycle of the species, as occurs with some marine crustaceans.

In principle, temperature is one of the main factors which is likely to influence synchronization of the procreation period of marine organisms. However, literature shows that reproduction pattern is not being determined by just one or a few factors, but rather by complex coordination of endogenous events (SASTRY 1983).

There are species which concentrate their period of procreation in theoretically colder months, such as Hemigrapsus nudus (Dana), which dwells among rocks and sandy substratum, both at $49^{\circ} \mathrm{N}$ (KNUDSEN 1964); others which procreate only in warmer months, such as Sesarma reticulatum (Say, 1817) and Sesarma cinerum (Bosc, 1802) (SEIPLE 1979); and those which reproduce during the whole year, with peaks in some months, such as Callinectes danae Smith, 1869 that in São Paulo, according to COSTA \& NEGREIROS-FRANSOZO (1998), the peak occurred from July to November.

Associations between temperature and reproduction may be related to better development conditions for larvae, in terms of food availability or more favorable 
conditions for upgrowth. However, in the case of tropical species, with procreation during the whole year, reproduction may be associated with a number of factors and not just temperature.

The conclusion is that $P$. spinimanus presents continuous reproduction in the region of Ubatuba, with peaks not directly associated with temperature. The differences in the reproductive activity of $P$. spinimanus, from one year to the next, must reflect adaptation strategies of the species that ensure permanence in that ecosystem, even in the face of environmental conditions that change from one year to the other, like the water temperature.

According to HARTNOLL \& GOULD (1988), it is accepted that the pattern of crustacean life cycle has been adapted, by evolutionary pressures, in order to maximize offspring survival in the following generation. If these patterns are adaptable, there could be possible correlation with wide ecological or environmental factors. However, general correlation with specific variables, such as depth, type of substratum and feeding method are not so easily differentiated.

As for the type of spawn, ARUL DHAS et al. (1980), in a histologic study on the gonads of the crab Portunus pelagicus, quote that some young oocytes can be found together with mature oocytes shortly before ovulation. The authors suggested that the presence of oocytes in different stages of development could indicate the presence of a parcelled egg batch for $P$. pelagicus, but they state that the young oocytes were probably produced at a later stage and did not receive enough stimuli to produce development. The young oocytes would not be used in the subsequent gametogenesis and would be reabsorbed after ovulation, which implies the coming of a totally new germination in the next gametogenesis. After egg extrusion, gonads become thin and pale, with some remaining oocytes, which are reabsorbed shortly thereafter.

Some $P$. spinimanus ovigerous females were captured with gonads in the RE/RU stage and which had recently extruded eggs, similarly to what was described above for P. pelagicus, and among these females, with eggs at the initial stage, many had restarted gonad development, stage RE/DG, indicating the presence of a total egg batch in $P$. spinimanus.

However, after a spawn $P$. spinimanus females are able to develop their ovaries again and to extrude new egg masses, without further copulation (since they store spermatophores in their spermatheca). In this case, there would be a total spawn, but with successive broods, which suggests a multiple total spawn during the reproductive period.

The reproductive capacity of the species may be evaluated by the presence of ovigerous females as well as by gonad activity. This capacity, in P. spinimanus, is considered to be quite high as it extends throughout the year with reasonable incidence. 


\section{REFERENCES}

Arul Dhas, M.M; T. Subramonian; S. Varadarajan \& P. GovindarJulu. 1980. Germinal zone active and oocyte differentiation in the marine crab Portunus pelagicus. Proc. Indian Nat. Sc. Acad., Part B, 46 (3): 287-292.

Batoy, C.B; J.F. CAMARGo \& B.C. Pilapil. 1987. Breeding season, sexual maturity and fecundity of the blue crab, Portunus pelagicus (L.) in selected coastal waters in Leyte and vicinity, Philippines. Ann. Trop. Res. 9: 157-177.

CAMP, D.K.; N.H. WHITING \& R.E. MARTIN. 1977. Nearshore Marine Ecology at Hutchinson Island, Florida: 1971-1974. V. Arthropods. Florida Mar. Res. Publ. (25): 1-63.

Cochran, W.G. \& G.M. Cox. 1978. Diseños experimentales. México, Editorial Trillas, $661 \mathrm{p}$.

CosTA, T.M. \& M.L. NegreIros-Fransozo. 1998. The reproductive cycle of Callinectes danae Smith, 1869 (Decapoda, Portunidae) in the Ubatuba region, Brazil. Crustaceana 71 (6): 615-627.

DRAPER, N.R. \& H. SMITH. 1966. Aplied regression analysis. New York, John Wiley and Sons, $407 \mathrm{p}$.

DUDLEY, D.L. \& M.H. JUDY. 1971. Occurrence of larval, juvenile, and mature crabs in the vicinity of Beaufort Inlet, North Carolina. NOAA Tec. Rep. 637: 1-10.

GoodMAN, L.A. 1964. Simultaneous confidence intervals for contrasts among multinomiae populations. Ann. Mathemat. Stat. 35 (2): 716-725.

- 1965. On simultaneous confidence intervals for multinomiae proportions. Technometrics 7 (2): 247-254.

HAEFNER JR., P.A. 1976. Distribution, reproduction and moulting of rock crab, Cancer irroratus Say, 1917, in the Mid-Atlantic Bight. Jour. Nat. Hist. 10: 377-397.

HARTNOLL, R.G. \& T. GOULD. 1988. Brachyuran life history strategies and the optimization of egg production. Symp. Zool. Soc. London 59: 1-9.

KNUDSEN, J.W. 1964. Observations on the reproductive cycles and ecology of the common Brachyura and crab-like Anomura of the Puget South, Washington. Pac. Science 18: 3-33.

Negreiros-Fransozo, M.L.; A. Fransozo; M.A.A. Pinheiro; F.L.M. MANTElatTo \& S. SANTOS. 1991. Caracterização física e química da Enseada da Fortaleza, Ubatuba, SP. Revta bras. Geociências 21 (2): 114-120.

Olsen, D.A.; A.E. Dammann \& J.A. La Place. 1978. Portunus spinimanus Latreille, a portunid crab with resource potential in the U.S. Virgin Islands. Mar. Fishery Rev. 40(7): 12-14.

PILLAY, K.K. \& N.B. NAIR. 1971. The annual reproductive cycles of Uca annulipes, Portunus pelagicus and Metapenaeus affins (Decapoda, Crustacea) from the South-west of coast Indian. Mar. Biol. 11: 152-166.

RYAN, E.P. 1967. Structure and function of the reproductive system of the crab Portunus sanguinolentus (Herbst) (Brachyura, Portunidae). II. Female system.

Proc. Symp. Crust. Mar. Biol. Assoc., India, 2: 522-544.

Santos, S.; M.L. Negreiros-Fransozo \& A. Fransozo. 1994. The distribution of the swimming crab Portunus spinimanus Latreille, 1819 (Crustacea, Brachyura, Portunidae) in Fortaleza bay, Ubatuba, SP, Brazil. Atlântica 16: 
$125-141$.

1995. Morphometric relationships and maturation in Portunus spinimanus Latreille, 1819 (Crustacea, Brachyura, Portunidae). Rev. Brasil. Biol. 55 (4): 545-553.

SASTRY, A.N. 1983. Ecological aspects of reproduction, p.179-270. In: W.B. VERNBERG (Ed.). The Biology of Crustacea: Environment adaptations. New York, Academic Press, Vol. 8, 383p.

SEILPLE, W. 1979. Distribution, habitat preferences and breeding periods in the crustaceans Sesarma cinerium and S. reticulatum (Brachyura, Decapoda, Grapsidae). Mar. Biol. 52: 77-86.

SuMPTON, W. 1990. Biology of the rock crab Charybdis natator (Herbst)

(Brachyura, Portunidae). Bull. Mar. Science 46(2): 425-431.

Recebido em 18.VI.1998; aceito em 20.X.1999. 